\title{
Review Article \\ Effect of Additives on Wood Pellet Physical and Thermal Characteristics: A Review
}

\author{
Dmitry Tarasov, Chander Shahi, and Mathew Leitch \\ Faculty of Natural Resources Management, Lakehead University, 955 Oliver Road, Thunder Bay, ON, Canada P7B 5E1
}

Correspondence should be addressed to Chander Shahi; cshahi@lakeheadu.ca

Received 26 December 2012; Accepted 13 January 2013

Academic Editors: S. Sun and S. Yildiz

Copyright (C) 2013 Dmitry Tarasov et al. This is an open access article distributed under the Creative Commons Attribution License, which permits unrestricted use, distribution, and reproduction in any medium, provided the original work is properly cited.

Additives play a major role in wood pellet characteristics and are a subject of major interest as they act as binding agents for the biomass raw material. Past research has reported the use of lignosulphonate, dolomite, starches, potato flour and peel, and some motor and vegetable oils as additives for wood pellet production. This paper reviews the available research on the effect of different additives on wood pellets' physical and thermal characteristics. It was found that lignosulphonate and starch additives improve the mechanical durability but tend to reduce the calorific value of the wood pellets. Motor and vegetable oil additives increase the calorific value minimally but significantly increase carbon monoxide emissions. Corn starch and dolomite additives also significantly increase carbon monoxide emissions. In order to produce wood pellets with desired physical and thermal characteristics, a suitable additive with the right biomass material should be used.

\section{Introduction}

The Canadian government is promoting clean energy usage; accordingly, the provincial governments have chalked out plans to become completely coal-free in the near future [1]. However, according to the International Energy Agency, in 2009 , wood energy that is considered clean comprised only $4 \%$ of Canada's total primary energy supplies [2]. Wood pellets have emerged as a very successful renewable fuel source for energy production, due mainly to their many beneficial characteristics, including high density and calorific value, low moisture content, and relative convenience of transportation and storage. Wood pellets are wood fuel made from compacted sawdust and other wood waste [3]. Residential use of the prime class wood pellets have $6 \pm 1 \mathrm{~mm}$ diameter and 3.15-40 $\mathrm{mm}$ length (EU standards) [4], and $5.84-7.25 \mathrm{~mm}$ diameter and $3.81 \pm 0.0381 \mathrm{~mm}$ length (USA Standards) [5].

Canada is emerging as one of the world leaders in wood pellet production. The wood pellet production capacity in Canada has grown from 300,000 tonnes in 1997 to 2.93 million tonnes in $2011[6,7]$. This growth is due in part to the European Union's (EU) renewable energy promotion policy, as $90 \%$ of total Canadian pellet production goes overseas while domestic usage is extremely low [8]. Price of wood pellets in Europe ranges from US\$215 to US\$275 per tonne, whereas in the North American market, the average domestic residential retail price ranges from US $\$ 175$ to US $\$ 250$ per tonne [9]. Wood pellet production plants are present in almost all provinces of Canada, but the majority of pellet production comes from Western Canada (British Columbia and Alberta).

The quality of wood pellets is determined by a few key parameters including moisture content $(\mathrm{MC})$, calorific value, amount of fines, mechanical durability, particle density, ash content, and ash melting point. These parameter values are defined in the prEn 14961-1 (EU) and PFI (United States of America) standards. The values of these physical and thermal parameters are affected by using different binding agents or additives in wood pellet production. According to the EU standards, additives that improve fuel quality, decrease emissions, or boost burning efficiency can make up to a maximum of $2 \%$ of the total mass of the wood pellets [10]. The most commonly used additives are lignosulphonate, starch, dolomite, corn or potato flour, and some vegetable oils [4]. These binding agents or additives also affect the production economics of the final product.

Lignosulphonate is a water-soluble anionic polyelectrolyte polymer, which is obtained as a by-product of the 
wood sulfite pulping process [11]. Lignosulphonates are used in animal feeds and have been considered as the most effective and popular binding agents for wood pellets. Normally $1 \%$ to $3 \%$ of lignosulphonates are used for effective binding of wood pellets [12]. Starch is formed from two polymers, amylose, a linear polysaccharide, and amylopectin, a large highly branched polysaccharide, and is obtained in various shapes and granular sizes when cereals or tubes are separated into protein and fiber components [13]. The shapes and granular sizes of the starch affect its distribution in the wood material and consequently affect the pellet abrasion. Other additives, like vegetable oil or dolomite, are added for better lubrication during the pelletizing process $[14,15]$. Binding agents are usually added to the production process either just before the core matrix pressing phase in the pilot-scale pelletizing machine [16], or as a continuous flow of raw material on a collector screw before the mixer buffer silo [17].

The binding agents also affect power consumption and usage of water during the wood pellet manufacturing process. Maize starch and lignosulphonate have been found to be better additives for power consumption per unit of wood pellet output as compared to the other additives $[17,18]$. With no additives, the specific energy consumption for poplar wood pellet production was found to be $138 \mathrm{kWh}$ per dry tonne [18]. The specific energy consumption value significantly decreased to $79 \mathrm{kWh}$ per dry tonne by adding $2.5 \%$ maize starch, to $128 \mathrm{kWh}$ per dry tonne by adding $2.5 \%$ lignosulphonate, and to $106 \mathrm{kWh}$ per dry tonne by adding 5\% lignosulphonate [18]. The lower specific energy consumption of using starch as an additive is due to the lubricating ability of starch. Water is added to the raw material before the pelletization process in order to obtain optimum moisture content. The use of additives affects the amount of water required in the wood pellet production process. For example, the use of dolomite as an additive increases water consumption significantly, whereas wheat starch does not have much effect on water usage [15].

Therefore, the past research shows that the additives and binding agents affect all the major characteristics of the wood pellets. The purpose of this study is to summarize the experimental data related to the effects of additives and binding agents on physical and thermal wood pellet characteristics. This literature review helps in identifying the need for further research in finding mixtures of additives and different raw materials for producing wood pellets having best physical and thermal characteristics, so that wood pellets remain competitive as a renewable energy option.

\section{Physical Characteristics}

The physical characteristics reviewed in this study include (i) moisture content, (ii) particle density and mechanical durability, and (iii) bulk density and pellet size.

2.1. Moisture Content. MC is expressed as a percentage of the original sample mass, and it has a strong influence on other wood pellet parameters, such as heating value, combustion efficiency, pellet durability, and bulk density. Different additives require different amounts of $\mathrm{MC}$ in the raw material in order to bind the material effectively. The use of starch as a binding agent requires $\mathrm{MC}$ for the raw material between $12.5 \%$ and $13.0 \%$, whereas lignosulphonate requires MC values between $9.0 \%$ and $10.5 \%$ for the pelletization process [18]. When additives are used for making wood pellets, these decrease the final MC of the wood pellet. For example, wood pellets made of standard raw material (with $9.3 \% \mathrm{MC}$ ) and $1 \%$ or $2 \%$ lignosulphonate (with $8 \% \mathrm{MC}$ ) mixture result in a final pellet MC of 5.9\% [17]. However, when the lignosulphonate dosage is increased to $2.5 \%, 5 \%$, and $7 \%$, it does not display a significant effect on the final MC of the wood pellet [18]. In case 5\% potato peel residue (with $77.8 \% \mathrm{MC}$ ) and dry raw material (with $3.3 \% \mathrm{MC}$ ) are mixed together, the resulting wood pellets have $2.9 \% \mathrm{MC}$ [17]. The use of starch significantly reduces the final wood pellet MC. Stahl et al. [13] found that when the raw material (with 12.1\% $\mathrm{MC}$ ) was mixed with $1 \%$ wheat starch, and the same amount of oxidized corn starch, the final pellet MC is reduced to $7.6 \%$. Increasing dosages of wheat and maize starch further reduces the pellet MC [13]. Interestingly, if lignosulphonate and maize starch are added at the same time ( $1 \%$ of lignosulphonate and $1 \%, 2 \%, 3 \%$, or $4 \%$ of maize starch), the final wood pellets MC decreases only by $0.5 \%[18]$.

From the above-mentioned literature, it is clear that the addition of starch has a higher impact in reducing the final wood pellet MC as compared to lignosulphonate. However, too much starch will make the final product extremely dry. The final MC of the wood pellet is very important, as it affects not only the calorific value, but also durability and abrasion of the product. Li and Liu [19] reported that a good quality pellet has MC ranging between $6 \%$ and $12 \%$. Wilson [20] found that the highest pellet durability index with red oak samples has MC of $10 \%$. Other studies also found that wood pellets having MC ranging between $9 \%$ and $14 \%$ are most durable and resistant to abrasion [21, 22].

2.2. Particle Density and Mechanical Durability. Table 1 presents particle density and mechanical durability of poplar pellets with different additives and a specific pelletization surface area. Particle density is the ratio of the sample mass and its volume including pore volume [23]. Single pellet density is variable and depends on wood pellet machine packaging pressure and wood species. Extremely high density is not good for combustion efficiency, as the access to oxygen is prevented when the wood elements are very tightly packed, and that consequently degrades the burning process. These strength parameters are particularly important for storage and transportation of wood pellets over long distances, as it is important to minimize dust and fracture formation during storage and transportation. These parameters do not exist in the prEN 14961-2 and PFI standards [4, 5]. However, according to the German and Austrian standards, a single pellet density should be between 1000 and $1400 \mathrm{~kg} / \mathrm{m}^{3}$ [24].

Mechanical durability is defined as abrasion resistance and mechanical strength as compressive and impact resistance [25]. According to the European standards, high-class pellet mechanical durability should not be less than $97.5 \%$, and according to the PFI standard, this parameter should 
TABLE 1: Particle density and mechanical durability of poplar pellets using different additives, with specific pelletization surface area of $5.6 \mathrm{~cm}^{2} / \mathrm{kW}[18]$.

\begin{tabular}{lccc}
\hline Additive & MC (\%) & $\begin{array}{c}\text { Particle density } \\
\left(\mathrm{kg} / \mathrm{m}^{3}\right)\end{array}$ & $\begin{array}{c}\text { Mechanical } \\
\text { durability }(\%)\end{array}$ \\
\hline LS 2.5\% & 9.9 & 960 & 98.0 \\
MS 2.5\% & 9.9 & 970 & 95.9 \\
LS 5\% & 8.5 & 1080 & 98.8 \\
MS 5\% & 9.8 & 960 & 97.3 \\
LS 7\% & 9.5 & 1060 & 98.4 \\
MS 7\% & 9.0 & 1000 & 96.4 \\
MS 0.95\% + LS 1.05\% & 6.3 & 1070 & 93.2 \\
MS 1.94\% + LS 1.06\% & 8.4 & 1030 & 95.6 \\
MS 2.94\% + LS 1.06\% & 8.0 & 1100 & 97.1 \\
MS 3.93\% + LS 1.07\% & 7.2 & 1130 & 97.1 \\
\hline
\end{tabular}

LS: lignosuphonate; MS: maize starch.

not be less than 96.5\% [4, 5]. MC, particle size, and rawmaterial chemical composition affect wood pellet mechanical durability [20]. The mechanical durability of wood pellets is stable with MC values ranging between $9 \%$ and $14 \%$ [21], and the influence of abrasion disappears for MC values between $8 \%$ and $12 \%$ [19]. If the raw material MC is lower than $7 \%$, pellets will not have the necessary strength characteristics, as there will not be enough moisture for lignin to form a strong bond with the pellet particles.

Mediavilla et al. [18] conducted a comparative study to analyze the impact of different additives (lignosulphonate, maize starch, and their different combinations) on the particle density and mechanical durability under similar initial conditions (same raw material, same dosage of additive, same $\mathrm{MC}$, and same compression rate). The particle density varied between $960 \mathrm{~kg} / \mathrm{m}^{3}$ and $1130 \mathrm{~kg} / \mathrm{m}^{3}$, and the mechanical durability varied between $93.2 \%$ and $98.8 \%$ for different additives and their combinations. The addition of lignosulphonate resulted in higher mechanical durability as compared to the addition of maize starch.

Nosek et al. [26] further found that using additives (such as motor oil, corn starch, sodium carbonate, urea, vegetable oil, and dolomite) at a dosage of $0.5 \%$ decreased the wood pellet particle density. The strongest effect on decreasing the wood pellet particle density was found when corn starch and dolomite were used as an additive [26]. Using softwood as a raw material, Kofman [14] found that $1 \%$ and $2 \%$ addition of binding agents (lignosulphonate and potato flour) increased wood pellet's mechanical durability from approximately $96 \%$ to $98 \%$. Addition of $1 \%$ of potato flour improved mechanical durability more than the addition of $1 \%$ of lignosulphonate; however, $2 \%$ dosage of either additive shows the same result [17]. Stahl et al. (2012) also found that the addition of starch additives increases wood pellet mechanical durability [13]. All types of starch (native wheat starch, oxidized corn starch, native potato starch, and oxidized potato starch) help in increasing mechanical durability as the starch dosage increases. Addition of $2.8 \%$ oxidized corn starch had the best overall effect among all the starches, with the mechanical durability index increasing from $93.6 \%$ (native wood) to 98.1\%.

2.3. Bulk Density and Pellet Size. Bulk density is a parameter, which directly affects storage and transportation costs, as higher bulk density promotes product compactness in the shipping container. Bulk density depends on pellet size (both length and diameter), single pellet density, and moisture content. Pellet size further impacts the pellet strength, as a longer pellet can be easily broken as compared to a shorter one. The bulk density of $6 \mathrm{~mm}$ diameter pellets (with average particle density of $1764 \mathrm{~kg} / \mathrm{m}^{3}$ ) is found to be $609 \mathrm{~kg} / \mathrm{m}^{3}$, compared to the bulk density of $8 \mathrm{~mm}$ diameter pellets (with average particle density of $1687 \mathrm{~kg} / \mathrm{m}^{3}$ ), which is found to be $621 \mathrm{~kg} / \mathrm{m}^{3}$ [27]. Pellet size (length) also affects the burning efficiency. Sikanen and Vilppo (2012) found that wood pellet burning temperature decreases by $31 \%$ and flue gas temperature by $25 \%$, as the pellet length increases from $5.8 \mathrm{~mm}$ to $13.1 \mathrm{~mm}$ [28]. The use of binding agents as additives has been found to have an effect on the pellet length. Stahl et al. (2012) found that starch additive significantly increases the wood pellet length when no cutting blade is used [13]. Raw materials with larger particle size and higher $\mathrm{MC}$ reduce bulk density of the product, while higher process temperatures and pressures increase the bulk density [12]. Tabil et al. (2011) and Samuelsseon et al. (2012) also found an inverse negative relationship between the moisture content and bulk density $[21,29]$. The bulk density of softwood pellets increases by $20-$ $25 \mathrm{~kg} / \mathrm{m}^{3}$ with an addition of $5 \%$ bark additives [30]. This is because bark contains $8-10$ times higher concentrations of metals, such as aluminum, iron, and sodium than in stem wood. Other additives, such as lignosulphonate and different types of starch, decrease the moisture content of wood pellets, thereby increasing the bulk density of the product.

\section{Thermal Characteristics}

The thermal characteristics reviewed in this study include (i) heating value, (ii) ash content, ash melting point and elemental composition, and (iii) emissions formation.

3.1. Heating Value. Heating value (calorific value) is the most important wood pellet characteristic, as higher heating value means higher energy output from the same amount of product and consequently lower cost for the customer. Heating value is either expressed as low heating value (LHV) or high heating value (HHV). LHV determines the maximum amount of heat generated excluding the heat of vaporization, whereas HHV is the heat value produced by total combustion of the fuel unit. Calorific value (kilo Jules/gram) is related to the concentrations of carbon, hydrogen, oxygen, sulphur, nitrogen, and ash present in the wood pellet sample and is calculated using the following equation [31]:

$$
\begin{aligned}
\mathrm{HHV}= & 0.3491 \mathrm{C}+1.1783 \mathrm{H}-0.1034 \mathrm{O} \\
& -0.0211 \mathrm{~A}+0.1005 \mathrm{~S}-0.0151 \mathrm{~N}
\end{aligned}
$$

where $\mathrm{C}, \mathrm{H}, \mathrm{O}, \mathrm{A}, \mathrm{S}$, and $\mathrm{N}$ represent the mass fractions of carbon, hydrogen, oxygen, ash, sulphur, and nitrogen, 
respectively. HHV is positively related to carbon, hydrogen, and sulphur concentration but negatively related to nitrogen and oxygen concentration. Therefore, if the biomass used for producing pellets is obtained from nitrogen-fixing species (e.g., alder trees), the calorific value of these wood pellets would be much lower. Wood bark is also known to contain more nitrogen than the wood $[32,33]$. Softwoods in general have a higher heating value than hardwoods [34]. The average gross calorific value of wood is $20.25 \mathrm{MJ} / \mathrm{kg}$ [4]. The presence of lignin also increases the heating value of the woody biomass [35]. The heating value is also affected by the thermal conductivity, which depends on the heat conductance during pellet storage $[36,37]$. The additives (lignosulphonate, potato flour, and potato peel residue) do not significantly impact the calorific value of the wood pellets [17]. However, $0.5 \%$ dosage of motor oil and vegetable oil increases calorific values, and $0.5 \%$ corn starch additive decreases calorific values by about $0.5 \mathrm{MJ} / \mathrm{kg}[26]$.

\subsection{Ash Content, Ash Melting Point, and Elemental Com-} position. Ash content is the percentage by weight of ash present in the wood pellet in relation to the fuel weight. High ash content will decrease the stove efficiency, and the stove requires cleaning more often. According to the EU standard, premium class wood pellet ash content should be less than $0.7 \%$, and PFI defines this parameter to be less than $1 \%[4,5]$. Kuokkanen et al. (2011) found that a supplement of $1 \%$ potato flour does not affect ash content, but $2 \%$ dosage of the same additive increases ash content from $0.5 \%$ (native wood) to $0.6 \%$. The $0.5 \%$ and $3 \%$ addition of dolomite also increases the ash content as compared to the reference sample $[15,17]$. When lignosulphonate is used at concentrations of $1 \%$ and $2 \%$, wood pellet ash content increases from $0.5 \%$ (native wood) to $0.6 \%$ and $0.8 \%$, respectively [17]. However, $0.5 \%$ additive of wheat starch significantly reduced ash formation by two times [15].

Ash melting point is affected by the chemical composition of the biomass used for making wood pellets. The concentrations of calcium and magnesium in the biomass increase, and the concentrations of potassium, and sodium in the biomass decrease the ash melting point of wood pellets $[4,38,39]$. Low ash melting point could result in ash related problems, like slagging and sediment formation in the combustion chamber [40,41], requiring frequent service of the wood pellet stove. According to the EU standard, the ash melting point has to be higher than $1200^{\circ} \mathrm{C}$ [42]. High concentrations of chlorine, potassium and sodium also enhance the likelihood of corrosion of the inner components of the stove or boiler system.

Additives change the wood pellet element composition, thereby affecting ash melting point behavior. Lignosulphonate additive at $1 \%$ and $2 \%$ dosages increases sodium content from $0.03 \mathrm{~g} / \mathrm{kg}$ (dry weight) in native wood to $0.1 \mathrm{~g} / \mathrm{kg}$ and $0.12 \mathrm{~g} / \mathrm{kg}$, respectively, and increases calcium content from $0.63 \mathrm{~g} / \mathrm{kg}$ (dry weight) in native wood to $1.13 \mathrm{~g} / \mathrm{kg}$ and $1.5 \mathrm{~g} / \mathrm{kg}$, respectively. Sulphur content also increases 10 times and 20 times, respectively, with $1 \%$ and $2 \%$ addition of lignosulphonate supplement [17]. Sulphur causes a major problem due to sulphates build up on the combustor heat transfer surfaces [35]. Lignin sulphonation also causes an increase in $\mathrm{SO}_{x}$ emissions [43]. However, no significant change in the potassium content was noted by adding lignosulphonate [17]. Nosek et al. (2011) found that $0.5 \%$ dolomite additive significantly increases ash melting point from $1200^{\circ} \mathrm{C}$ (native pellets) to approximately $1500^{\circ} \mathrm{C}$, while other additives did not show any significant effect on ash melting point. However, the ash melting point is significantly impacted by using bark additive [26]. 5\% of bark additive increased the ash-melting point $\left(1230^{\circ} \mathrm{C}\right)$ of pure wood (scots pine) pellets to $1567^{\circ} \mathrm{C}$ [30]. Bark also contains large concentrations of silicium (Si) for protection. Whereas the concentration of $\mathrm{Si}$ is about $150 \mathrm{mg} / \mathrm{kg}$ in wood stem, it is as high as $2,000 \mathrm{mg} / \mathrm{kg}$ in coniferous bark and $10,000 \mathrm{mg} / \mathrm{kg}$ in hardwood bark [44]. Si forms potassium silicates at high temperature, which reduces the combustion efficiency of wood pellets $[45,46]$.

3.3. Emissions Formation. Wood fuel is considered a renewable energy source and can help decrease the Earth's atmospheric $\mathrm{CO}_{2}$ concentration levels, if it replaces fossil fuels for energy production $[43,47]$. The greenhouse gas emissions during wood pellet production and combustion are much lower compared to burning fossil fuels $[48,49]$. However, wood pellets cannot be considered as $\mathrm{CO}_{2}$ neutral energy source [50]. The carbon emissions for wood pellets is higher than for wood chips because of the additional energy consumed in wood pellet production stages, like drying and pelletizing. The amount of $\mathrm{CO}_{2}$ emission varies from $30 \mathrm{~kg} / \mathrm{MWh}$ to $106 \mathrm{~kg} / \mathrm{MWh}$ and depends on the biomass species used, its source and the method for drying and pelletization [47]. The use of additives in wood pellets has been found to further increase the greenhouse gas emissions. For example, lignosulphonate addition significantly increases sulphur content [14], resulting in increased $\mathrm{SO}_{x}$ emission $[24,51]$. Although the addition of corn starch $(0.3 \%$ and $0.5 \%)$ and dolomite (0.1\%) decreases $\mathrm{SO}_{x}$ emissions from $6 \mathrm{mg} / \mathrm{m}^{3}$ to $4 \mathrm{mg} / \mathrm{m}^{3}$, these additives significantly increase carbon monoxide (CO) emissions [26]. Pellets with no additives emit around $250 \mathrm{mg} / \mathrm{m}^{3}$ of $\mathrm{CO}$ emissions, whereas pellets with $0.3 \%$ corn starch additive emit around $550 \mathrm{mg} / \mathrm{m}^{3}$ of CO, and with $0.5 \%$ of dolomite additive emit around $700 \mathrm{mg} / \mathrm{m}^{3}$ of CO [26]. However, no significant influence on $\mathrm{NO}_{x}$ emissions has been found [26].

\section{Conclusions}

The purpose of this study was to summarize the current state of the literature related to the effects of additives and binding agents on wood pellet physical and thermal characteristics. The physical characteristics reviewed in this study include (i) moisture content, (ii) particle density and mechanical durability, and (iii) bulk density and pellet size; whereas the thermal characteristics reviewed include (i) heating value, (ii) ash content, ash melting point, and elemental composition, and (iii) emissions formation. The findings of this paper can be summarized as follows.

The additives act as a lubricant and increase the production rate and decrease the energy consumption per unit output of wood pellets. Starch additives reduce the final 
moisture content more than lignosulphonate additives. However, too much starch will make the final product extremely dry, which affects mechanical durability of the wood pellets. Lignosulphonate additives result in the best mechanical durability values for wood pellets but do not display high particle density. Additives, such as motor oil, corn starch, sodium carbonate, urea, vegetable oil, and dolomite decrease the wood pellet particle density. However, corn starch and dolomite additives are the most effective in reducing the wood pellet particle density. All types of starch (native wheat starch, oxidized corn starch, native potato starch, and oxidized potato starch) increased the mechanical durability of the wood pellets, with the best results for mechanical durability obtained by adding oxidized corn starch.

Lignosulphonate does not affect the calorific value of the wood pellets, but significantly increases sodium and sulphur content, and consequently increases $\mathrm{SO}_{x}$ emissions. Motor and vegetable oil additives increase the calorific value minimally and corn starch and dolomite additives reduce the calorific values of wood pellets. Wheat starch additive significantly reduces ash formation, but dolomite additive increases ash formation as well as ash melting point in the wood pellets combustion. Both corn starch and dolomite additives significantly increase carbon monoxide emissions. Therefore, each additive has results in unique physical and thermal characteristics when used with different biomass materials. Further research is required in identifying mixtures of additives and different raw materials for producing wood pellets having the desired physical and thermal characteristics, so that wood pellets remain competitive as a renewable energy option.

\section{References}

[1] Ministry of Energy of Canada, Ontario's Long-Term Energy Plan, Ministry of Energy of Canada, Ontario, Canada, 2010.

[2] The UNECE/FAO, Forest Products Annual Market Review, 20082009, United Nations, New York, NY, USA, 2009.

[3] R. Sikkema, "Improvement of trade statistics on bioenergy," in Proceedings of the IEA Workshop Development of meaningful statistics, pp. 1-20, IEA, Paris, France, 2008.

[4] G. Thek and I. Obernberg, The Pellet Handbook: The Production and Thermal Utilization of Biomass Pellets, Earthscan, London, UK, 2010.

[5] Pellet Fuel Institute, Pellet Fuels Institute Standard Specification For Residential/Commercial Densified Fuel, Pellet Fuel Institute, Arlington, Va, USA, 2010.

[6] D. Bradley, Canada Report on Bioenergy 2010, Canadian Bioenergy Association, Ottawa, Canada, 2010.

[7] G. Murray, Canadian Wood Pellet Update. PFI Annual Conference, Wood pellet association of Canada, Ponte Vedra Beach, Fla, USA, 2011.

[8] S. Jamieson, One Home at Time, Canadian Biomass Journal, Ontario, Canada, 2010.

[9] C. Harper, Wood Pellets Becoming a primary Product, U.S. Endowment for Forestry and Communities and the National Association of State Foresters, Greenville, SC, USA, 2011.

[10] European Pellet Council, Handbook for the Certification of Wood Pellets for Heating Purposes, European Pellet Council, Brussels, Belgium, 2011.
[11] S. Lebo, J. Gargulak, and T. McNally, 'Lignin', Kirk-Othmer Encyclopedia of Chemical Technology, John Wiley \& Sons, New York, NY, USA, 2001.

[12] J. S. Tumuluru, C. Wright, J. R. Hess, and K. Kenney, "A review on biomass densification technologies for energy application," Biofules, Bioproducts and Biorefining Journal, vol. 5, pp. 683-707, 2010.

[13] M. Stahl, J. Berghel, S. Frodeson, K. Granström, and R. Renström, "Effects on Pellet properties and energy use when starch is added in the wood-fuel pelletizing process," Energy Fuels Journal, vol. 26, no. 3, pp. 1937-1945, 2012.

[14] P. Kofman, “The production of wood pellets," Processing/ Products 10, Coford Connects, Dublin, Ireland, 2010.

[15] BIOMASA Association, The Effect of Additives for Production Costs and Parameters of Wood Pellets, BIOMASA Association, Kysucky Lieskovec, Slovak Republic, 2011.

[16] M. Kuokkanen, T. Kuokkanen, and V. Pohjonen, "The development steps in eco-efficient pellet production and technology," in Proceedings of the EnePro Conference, Energy Research at the University of Oulu, pp. 36-40, University of Oulu, Oulu, Finland, 2009.

[17] M. Kuokkanen, T. Vilppo, T. Kuokkanen, T. Stoor, and J. Niinimaki, "Additives in wood pellets," BioResources Journal, vol. 4, no. 6, pp. 4331-4355, 2011.

[18] I. Mediavilla, L. S. Esteban, and M. J. Fernández, "Optimisation of pelletisation conditions for poplar energy crop," Fuel Processing Technology Journal, vol. 104, pp. 7-15, 2012.

[19] Y. Li and H. Liu, "High-pressure densification of wood residues to form an upgraded fuel," Biomass and Bioenergy, vol. 19, no. 3, pp. 177-186, 2000.

[20] T. Wilson, Factors affecting pellets durability [M.S. thesis], A Thesis in Agricultural and Biological Engineering, Department of Agricultural and Biological Engineering, The Pensylvania State University, University Park, Pa, USA, 2010.

[21] L. Tabil, P. Adapa, and M. Kashaninejad, "In biomass feedstock pre-processing: densification," in Biofuel's Engineering Process Technology, M. A. Dos Santos Bernardes, Ed., pp. 439-464, InTech, New York, NY, USA, 2011.

[22] I. Obernberger and G. Thek, "Physical characterisation and chemical composition of densified biomass fuels with regard to their combustion behaviour," Biomass and Bioenergy, vol. 27, no. 6, pp. 653-669, 2004.

[23] M. Temmermana, F. Rabiera, P. D. Jensenb, H. Hartmannc, and T. Böhmc, "Comparative study of durability test methods for pellets and briquettes," Biomass and Bioenergy Journal, vol. 30, no. 11, pp. 964-972, 2006.

[24] B. Hahn, Existing Guidelines and Quality Assurance for Fuel Pellets-Pellets for Europe Project, UMBERA, Umweltorientierte Betriebsberatungs, Forschungs und Entsorgungs-Gesellschaft m.b.H, Schiestattring, Austria, 2004.

[25] N. Kaliyan and R. Vance Morey, "Factors affecting strength and durability of densified biomass products," Biomass and Bioenergy, vol. 33, no. 3, pp. 337-359, 2009.

[26] R. Nosek, J. Jandačka, and M. Holubcik, "Increasing the melting temperature of ash by adding different types of additives into wood pellets," Care Tech 2011, University of Zilina, Zilina, Slovakia, 2011.

[27] M. Wu, D. Schott, and G. Lodewijks, "Physical properties of solid biomass," Biomass and Bioenergy Journal, vol. 35, no. 5, pp. 2097-2098, 2011. 
[28] L. Sikanen and T. Vilppo, "Small scale pilot combustion experiments with wood pellets- the effect of pellet lenght," The Open Renewable Energy Journal, vol. 5, pp. 1-6, 2012.

[29] R. Samuelsson, S. Larsson, M. Thyrel, and T. Lestander, "Moisture content and storage time influence the binding mechanisms in biofuel wood pellets," Applied Energy Journal, vol. 99, pp. 109-115, 2012.

[30] T. Filbakk, R. Jirjis, J. Nurmi, and O. Høibø, “The effect of bark content on quality parameters of Scots pine (Pinus sylvestris L.) pellets," Biomass and Bioenergy, vol. 35, no. 8, pp. 3342-3349, 2011.

[31] S. Gaur and T. Reed, Thermal Data For Natural and Synthetic Fuels, Marcel Dekker, New York, NY, USA, 1998.

[32] V. Francescato, E. Antononi, and L. Bergomi, Wood Fuels Handbook. Italian Agrioforestry Energy Association, Italian Agriforestry Association, Rome, Italy, 2008.

[33] T. D. Schowalter and J. J. Morrell, "Nutritional quality of Douglas-fir wood: effect of vertical and horizontal position on nutrient levels," Wood and Fiber Science, vol. 34, no. 1, pp. 158$164,2002$.

[34] A. J. Baker, "Wood fuel properties and fuel products from woods," in Fuelwood Management and Utilization Seminar, pp. 14-25, Michigan State University, East Lansing, Mich, USA, 1983.

[35] A. Demirbas, "Relationships between lignin contents and heating values of biomass," Energy Conversion and Management, vol. 42, no. 2, pp. 183-188, 2001.

[36] W. Guo, J. C. Lim, X. Bi, S. Sokhansanj, and S. Melin, "Determination of effective thermal conductivity and specific heat capacity of wood pellets," Fuel, vol. 103, pp. 347-355, 2013.

[37] W. Guo, J. C. Lim, and S. Melin, Thermal Conductivity of Pellets, University of British Columbia, British Columbia, Canada, 2009.

[38] S. Paulrud, Upgraded Biofuels-effects of quality on processing, handling characteristics, combustion and ash melting [Ph.D. thesis], Swedish University of Agricultural Sciences, Umea, Sweden, 2004.

[39] J. Werther, M. Saenger, E. U. Hartge, T. Ogada, and Z. Siagi, "Combustion of agricultural residues," Progress in Energy and Combustion Science, vol. 26, no. 1, pp. 1-27, 2000.

[40] M. Öhman, C. Boman, H. Hedman, A. Nordin, and D. Boström, "Slagging tendencies of wood pellet ash during combustion in residential pellet burners," Biomass and Bioenergy, vol. 27, no. 6, pp. 585-596, 2004.

[41] M. Hansen, A. Jein, S. Hayes, and P. Bateman, English Handbook for Wood Pellet Combustion, Pellet Atlas, Muenchen, Germany, 2009.

[42] D. Bernhardt, M. Pohl, K. Gebauer, S. Unz, and M. Beckmann, Biogenous Residues for the Use as Wood Pellet Equivalent Fuels, Thermal Treatment Technologies \& Hazardous Waste Combustors, Jacksonville, Fla, USA, Technical University Dresden, Institute of Power Engineering, Dresden, Germany, 2009.

[43] M. Olsson, J. Kjällstrand, and G. Petersson, "Specific chimney emissions and biofuel characteristics of softwood pellets for residential heating in Sweden," Biomass and Bioenergy, vol. 24, no. 1, pp. 51-57, 2003.

[44] F. Biedermann and I. Obernberger, Ash-Related Problems During Biomass Combustion and Possibilites for a sustainble Ash utilization, BIOS Bioenergiesysteme GmbH, Graz, Austria, 2011.

[45] S. Paulrud, C. Nilsson, and M. Öhman, "Reed canary-grass ash composition and its melting behaviour during combustion," Fuel, vol. 80, no. 10, pp. 1391-1398, 2001.
[46] L. L. Baxter, T. R. Miles, T. R. Miles et al., "The behavior of inorganic material in biomass-fired power boilers: field and laboratory experiences," Fuel Processing Technology, vol. 54, no. 1-3, pp. 47-78, 1998.

[47] The Government of the Northwest Territories , BW McCloy, Associates Inc, NWT Wood Pellet Pre-Feasibility Analysis, FPInnovations, Forintek Division, Vancouver, British Columbia, 2009.

[48] J. Bates, Full Fuel Cycle Atmospheric Emissions and Global Warming Impacts From UK, Stationary Office, London, UK, 1995.

[49] J. Bates and S. Henry, Carbon Factor for Wood Fuels for the Supplier Obligation, AEA Technology, Oxfordshire, UK, 2009.

[50] E. Roth, What Can We Expect from Wood Pellets? Leonardo ENERGY, Paris, France, 2006.

[51] P. Lehtikangas, Quality Properties of Fuel Pellets From Forest Biomass, The Swedish University of Agricultural Sciences, Uppsala, Sweden, 2002. 

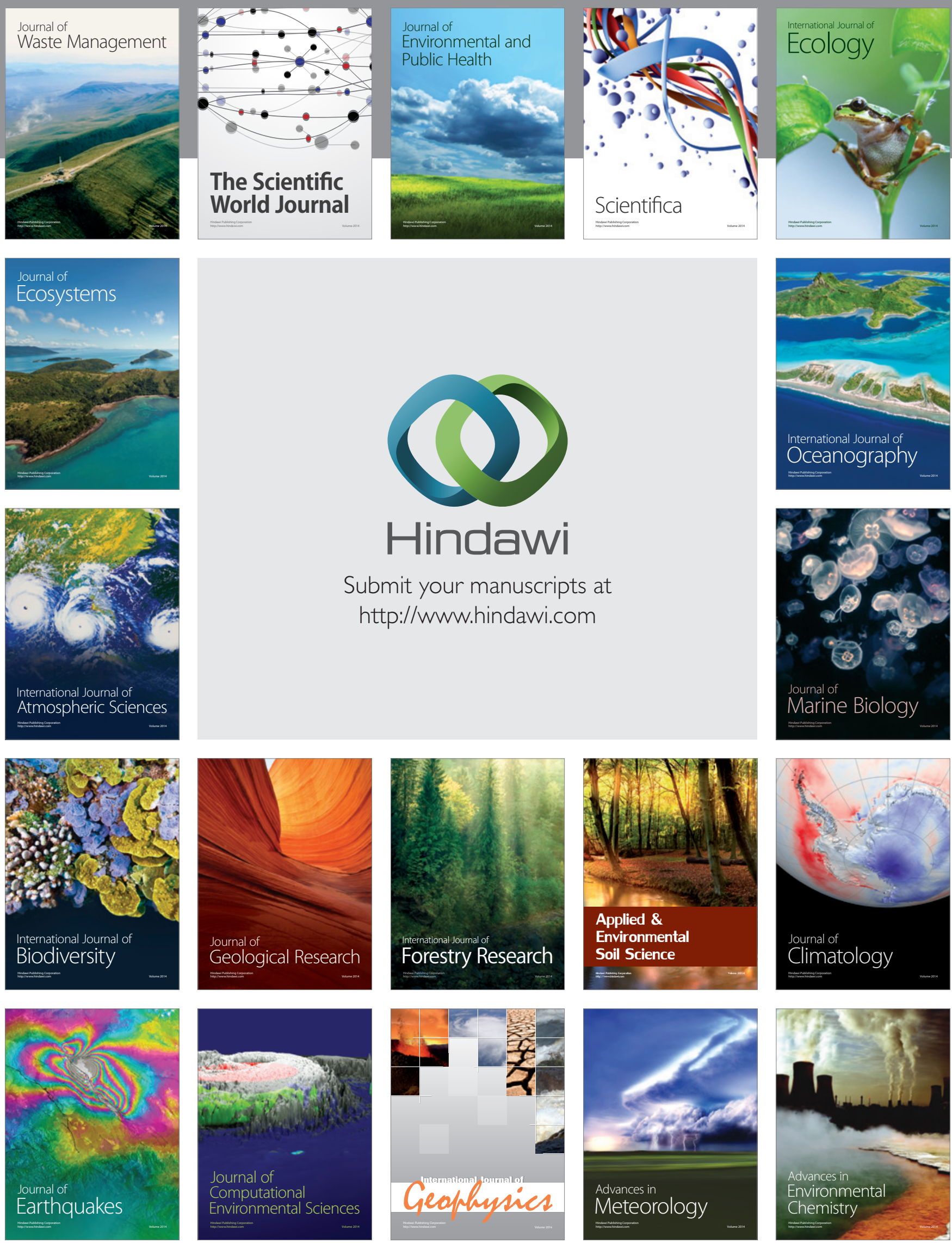